\title{
A MEM-based Analysis of Volatility Spillovers in East Asian Financial Markets
}

\author{
Robert F. Engle \\ Department of Finance, Stern School of Business, NYU \\ (rengle@stern.nyu.edu) \\ Giampiero M. Gallo* Margherita Velucchi \\ Dipartimento di Statistica “G. Parenti”, Università di Firenze \\ (gallog@ds.unifi.it)（velucchi@ds.unifi.it)
}

This version: July, 20, 2008

\begin{abstract}
Transmission mechanisms in financial markets reflect the degree of integration of capital markets, as well as the relative importance of real economies. Market volatility has components which may behave differently across quiet and turbulent periods, but appear to behave in similar ways from market to market. In this paper we suggest a Multiplicative Error Model (MEM) approach to study volatility spillovers among a set of markets, using as a proxy, the market daily range. We model the dynamics of the expected volatility of one market including interactions with the past daily ranges of other markets, building a fully interdependent model. We analyze eight East Asian markets in the period 1995-2006, devoting particular attention to the treatment of the 1997-1998 turbulent period. We find no evidence of independent markets while several interdependence relationships can be stressed. Hong Kong turns out to be the most important market while Taiwan seems to have suffered quite limited effects from the crisis. Impulse response functions and multiperiod forecast profiles are developed and suggest a build-up in the spillover effects.
\end{abstract}

\section{Introduction}

Transmission mechanisms across financial markets have been extensively investigated, especially in conjunction with some crisis episodes and the possibility that shocks to one market spill over to other. Volatility behaves differently between quiet and turbulent periods, but often in similar ways across integrated markets. The traditional literature on

\footnotetext{
*Corresponding author: Dipartimento di Statistica "G.Parenti" - Università di Firenze, Viale G.B. Morgagni, 59 - 50134 Firenze, Italy. A preliminary version of this paper was presented at the International Workshop on Computational and Financial Econometrics, University of Geneva, Switzerland, April 20-22, 2007. Thanks are due to participants for their comments. Financial support from the Italian MIUR under grant PRIN 2006131140_004 is gratefully acknowledged.
} 
contagion focuses on variations in these links during crisis periods via an increase of correlations of returns across markets (Forbes and Rigobon, 2002); the multivariate GARCH literature analyzes the behavior of conditional variances and covariances, possibly inserting a Markov switching behavior to account for sudden surges in volatility (Edwards and Susmel, 2001 and 2003).

In this paper we will focus on the 1997-1998 crisis which hit East Asia as a leading case of interdependencies among markets to illustrate the capability of the Multiplicative Error Model (Engle, 2002) in capturing the dynamic relationships among volatility (measured as daily range) in different markets. Our goal is to provide an analytical tool to detect significant relationships among markets, the impact of asymmetric effects related to positive and negative market returns and the possible different values of some coefficients in meaningful subperiods (namely, during the crisis and after). Since the Multiplicative Error Model we adopt can be seen as a Nonlinear Vector Autoregressive model, it is natural to derive forecasts starting from market situations observed at meaningful dates (July 1997, October 1997 and September 2001) and to represent interrelationships by means of the profile of responses to individual market shocks.

Our approach is similar in spirit to the one by Diebold and Yilmaz (2008); they also use the range (at weekly frequency) but adopt a linear VAR model on a number of international indices. Our contribution is to show that a multivariate MEM has a very simple structure: it is easy to estimate and it allows for model selection to prune insignificant links. We analyze eight East Asian markets in the period 1995-2006, devoting particular attention to the treatment of the 1997-1998 turbulent period. We show that for some of the markets the crisis has brought about significant changes of the dynamics, for others the links are stable across subperiods. The average level of volatility was the highest during the crisis and higher in the more recent period than at the beginning of the sample. One interesting feature of the MEM estimated on our data is that the impulse response functions signal a significant delay in the full development of the effects following a shock in one market. On a substantive level, the results indicate the crucial role of Hong Kong in influencing other markets, the relative little spillovers from Thailand to other markets (other than Hong Kong) in July 1997, and the greater diffusion of the crisis in October 1997 (the unfolding is well reproduced by our forecasts). The September 2001 episode, on the other hand shows little evidence of turbulence and spillovers across markets.

The structure of the paper is as follows: in Section 2 we describe the data we used, we introduce the volatility proxy (the daily range on market indices) which has proved to possess good theoretical and empirical properties (Alizadeh et al., 2002; Engle and Gallo, 2006; Diebold and Yilmaz, 2008); then we present some results in the literature about the East Asian crisis to highlight methodologies adopted and to summarize the main empirical findings. In Section 3, we introduce the specification of the multivariate Multiplicative Error Models in which we allow for lagged values of volatility in all markets to be present in the specification for the conditional expectation of market volatilities; the own market effects are split into two separate terms according to whether the lagged market returns are positive or negative. In the specification the crisis period is represented by a dummy variable, in itself and interacting term with each lagged volatility. The estimated models are then reduced to more parsimonious representations. Section 4 presents the empirical analysis (nonlinear impulse responses and forecasting) carried out with the estimated models retained. Section 5 contains some concluding remarks. 


\section{The Data}

We have concentrated our attention on eight Asian markets (Hong Kong (HK), Indonesia (IN), South Korea (KO), Malaysia (MA), the Philippines (PH), Singapore (SI), Taiwan (TA), Thailand (TH)) on a sample period which spans eleven years from July 14, 1995 to Oct. 3, 2006 (2754 observations). The indices are depicted in Figure 1 with a shaded area which covers the period between July 2, 1997 to Dec. 31, 1998, commonly reckoned to be a period which should fully encompass the inception and spread of turbulence on the Asian markets, following the devaluation of the Thai Baht.

The proxy for volatility adopted is the daily range $h l_{t}$, defined as

$$
h l_{t}=k \log \left(\text { high }_{\mathrm{t}}\right)-\log \left(\operatorname{low}_{\mathrm{t}}\right),
$$

where $k$ is a multiplicative constant. The range can be interpreted as the maximum intradaily return obtainable on a long position entered at the lowest price and closed at the highest (if the former precedes the latter) or on a short position if the highest price was recorded earlier than the lowest. Following Parkinson (1980) who has established its statistical properties relative to the variance parameter in an underlying continuous time diffusion process, range-derived measures have been recognized as a good volatility indicator: Alizadeh et al. (2002) have provided extensive discussion on the properties of the log range defined as the log of the difference between the highest and the lowest intra-daily price; Engle and Gallo (2006) have shown that dynamically the range as defined above has good explanatory power in predicting future values of squared returns or realized variance. For the markets at hand the descriptive statistics are shown in Table 1.

\begin{tabular}{|c|c|c|c|c|c|c|c|c|}
\hline & HK & IN & KO & MA & PH & SI & TA & TH \\
Mean & 0.682 & 0.786 & 0.933 & 0.627 & 0.608 & 0.583 & 0.753 & 0.829 \\
Max & 5.960 & 8.915 & 4.563 & 12.186 & 4.306 & 5.626 & 4.126 & 5.354 \\
Min & 0.124 & 0.095 & 0.109 & 0.096 & 0.102 & 0.102 & 0.129 & 0.156 \\
St.Dev & 0.442 & 0.619 & 0.547 & 0.625 & 0.404 & 0.423 & 0.430 & 0.539 \\
Skewness & 2.781 & 3.384 & 1.454 & 6.009 & 2.732 & 3.467 & 1.719 & 2.521 \\
Kurtosis & 18.844 & 24.410 & 5.556 & 74.042 & 16.145 & 25.616 & 7.810 & 14.198 \\
\hline
\end{tabular}

Table 1: Descriptive Statistics on Daily Range, Eight Asian Markets. July 14, 1995 to Oct. 3, 2006 (2754 observations).

In this paper, we investigate the dynamics of volatility in these 8 Asian markets before, during and after the 1997-1998 crisis and focus on the existence of volatility spillovers among them. The theoretical literature on this topic is extensive (see Claessens and Forbes 2001; cf. Pericoli and Sbracia, 2003, as a guideline to the existing literature). A variety of methodologies were adopted, e.g.

- Probit/Logit models where a dichotomous variable representing crisis assumes value equal to one or zero in a country if the corresponding period was marred or not by a crisis ( Eichengreen et al., 1996; Caramazza et al., 2004; Van Rijckeghem and Weder, 2001); 
HONGKONG

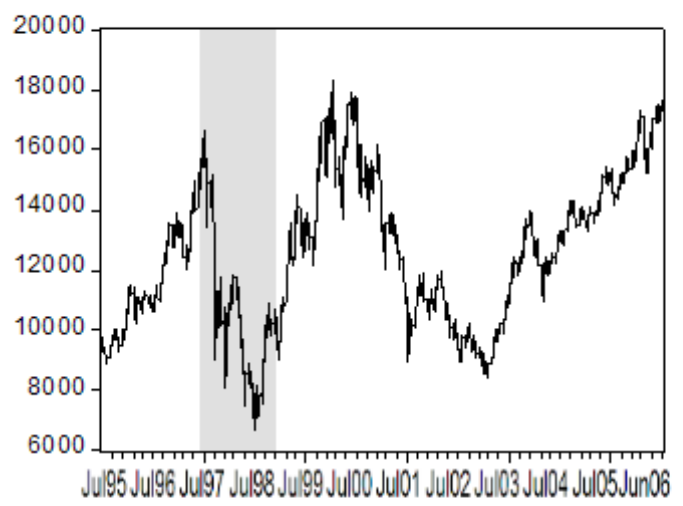

KOREA

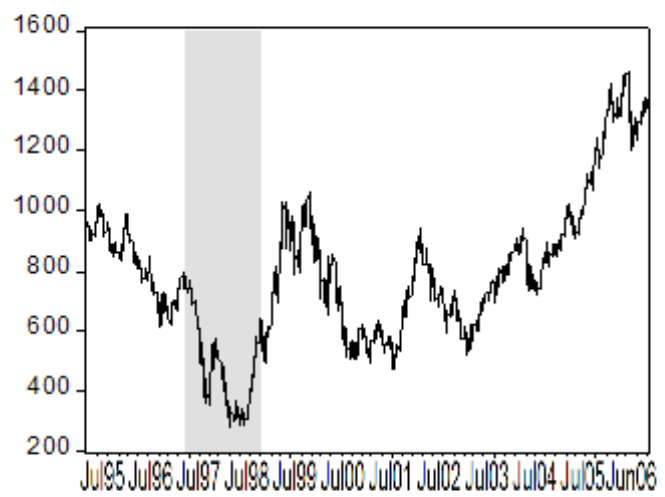

PHILIPPINES

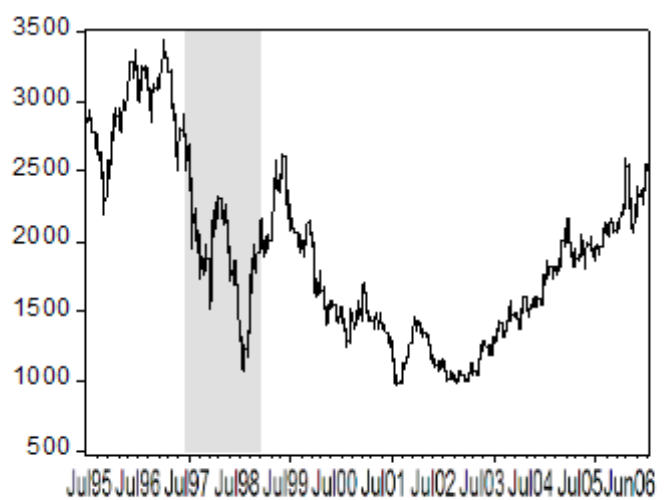

TAIWAN

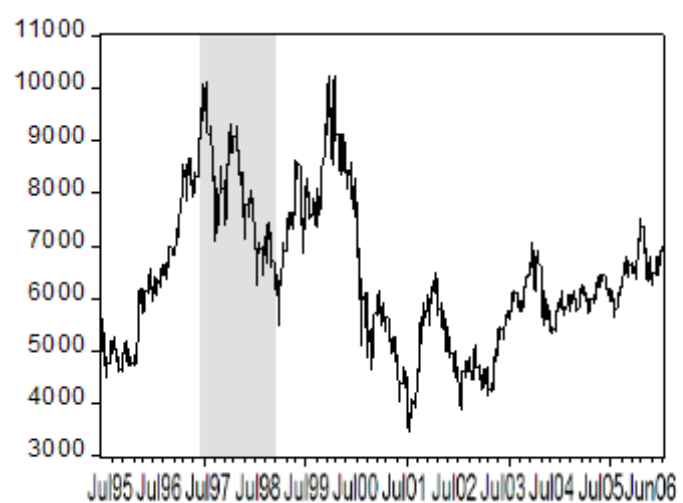

INDONESIA

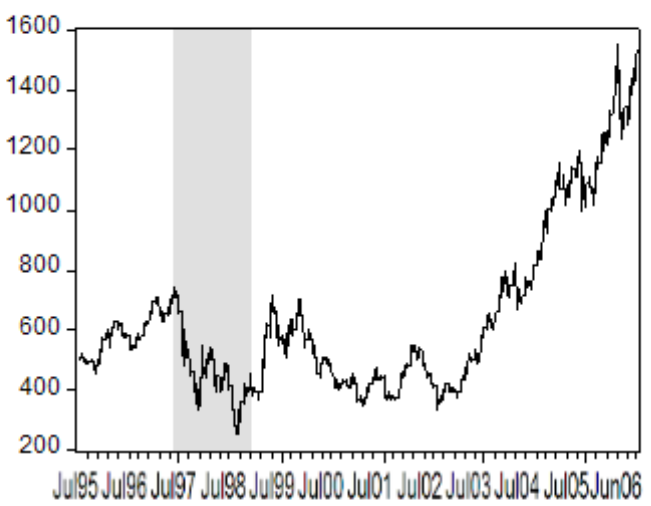

MALAYSIA

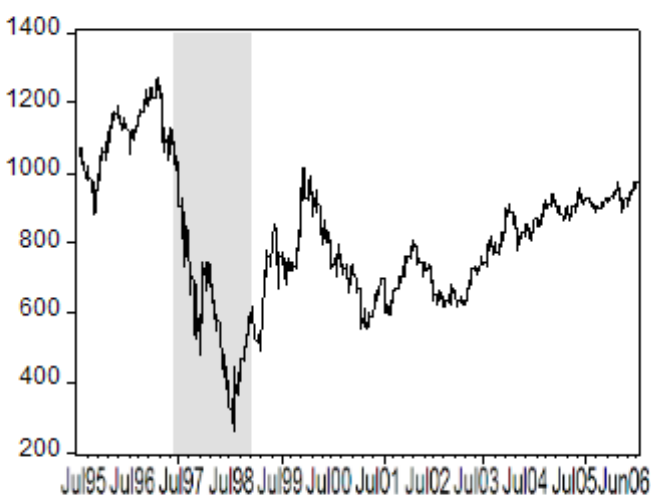

SINGAPORE

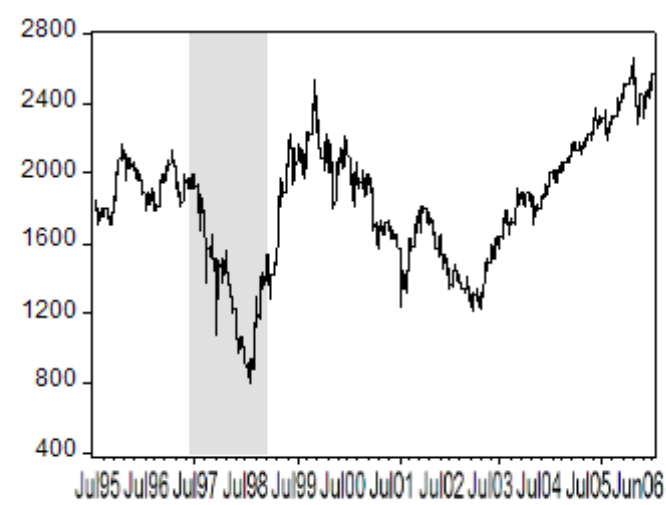

THAILAND

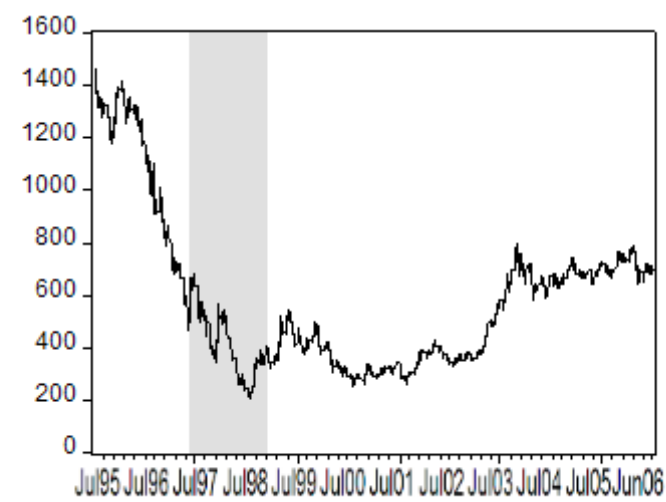

Figure 1: Stock Indices - July 1995 - Oct 2006. Shaded area July, 2, 1997 - Dec. 31, 1998. 
HK_HILO

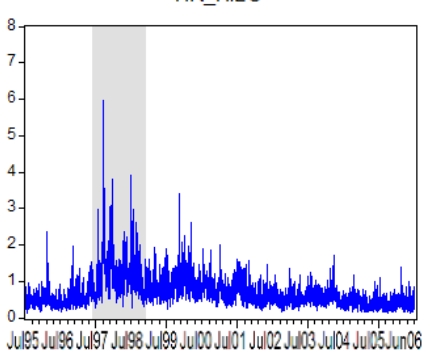

MA_HILO

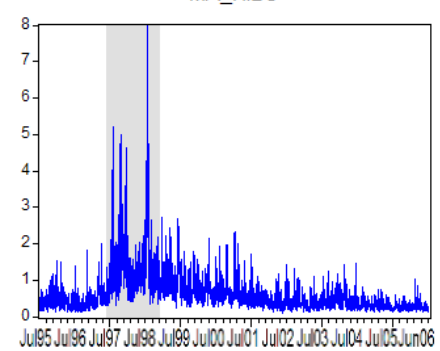

TA_HILO

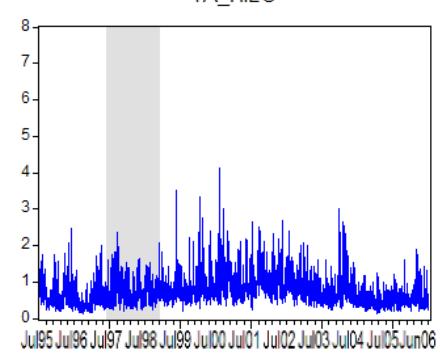

IN_HILO

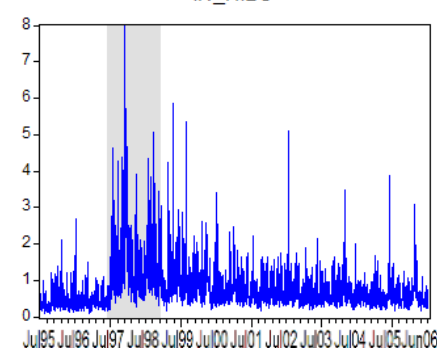

PH_HILO

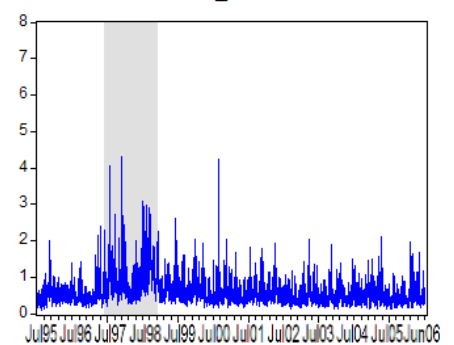

TH_HILO

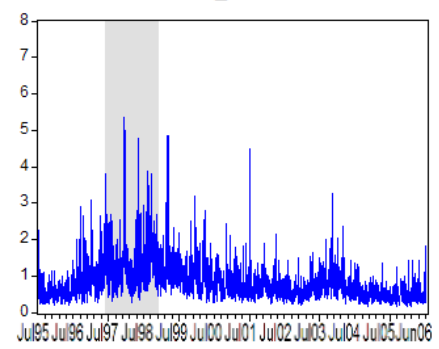

KO_HILO

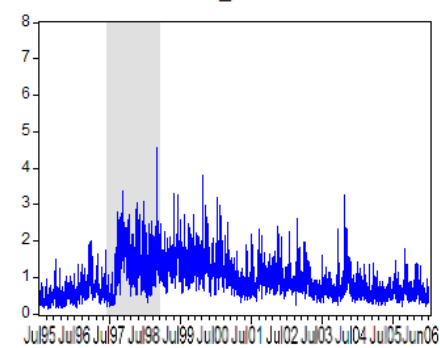

SI_HILO

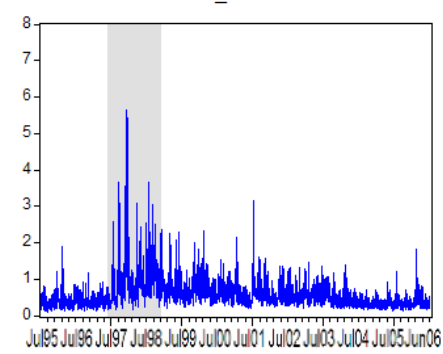

Figure 2: Time series plots of $h l_{t}$ for all markets. Shaded area between July 2, 1997 and Dec. 31, 1998. Truncated vertical axis leaves out one value for Indonesia (8.915) and one for Malaysia (12.186). 
- analyses linked to the predictive ability of leading indicators representing economic fundamentals (Kaminsky, 1999; Kaminsky et al., 1998; Hardy and Pazarbaşoĝlu,1998)

- GARCH models (Engle et al., 1990; Fleming and Lopez, 1999, Edwards, 1998) and changes in correlation (Forbes and Rigobon, 2002).

- Regime switching models (Edwards and Susmel, 2001, 2003; Fratzscher, 2003; Gallo and Otranto, 2007).

Generally, the empirical results confirm a certain degree of interdependence among markets, independently of the definition chosen.

Table 2 shows a brief summary of the empirical analysis on Asian crisis. A variety of different econometric approaches have been used to describe how shocks propagate, whether some kind of relationships among different markets exist and how they change, if any, during a crisis. Results based on these techniques all reach the same conclusion: some dependence between Asian markets exist, Hong Kong plays a very important role in the region and the interrelationships changed during the crisis period. This sets the stage for our analysis.

\section{The ME Model for the Asian Markets}

We will part from the existing literature introducing a new model, the Multiplicative Error Model, estimated on a simultaneous structure on the range data for the eight markets.

We will assume that, conditional on the information set $I_{t-1}$, an appropriate model for market $i$ is the Multiplicative Error Model written as

$$
h l_{i, t} \mid I_{t-1}=\mu_{i, t} \epsilon_{i, t},
$$

where $\epsilon_{i, t} \mid I_{t-1} \sim \operatorname{Gamma}\left(\phi_{i}, 1 / \phi_{i}\right)$. Given the unit expectation of the innovation term, $\mu_{i, t}$ is the conditional expectation of $h l_{i, t}$. Its simplest specification is a base $\operatorname{MEM}(1,1)$ (extended to a $\operatorname{MEM}(2,1)$ to capture more complex structure in the autocorrelation of the innovations):

$$
\mu_{i, t}=\omega_{i}+\beta_{i} \mu_{i, t-1}+\alpha_{i, i} h l_{i, t-1}\left(+\psi_{i} h l_{i, t-2}\right) .
$$

This base specification can include other terms which are of interest in the present framework ${ }^{1}$ :

1. the lagged daily ranges observed in other markets to link together different markets $h l_{j, t-1}, j \neq i$

2. time dummies to accommodate specific periods which are known to have been characterized by specific turbulence or low average volatility. For the empirical analysis

\footnotetext{
${ }^{1}$ We use a single subscript when the corresponding effect comes just from the same market and a double subscript for interdependence effects. Also, we prefer not to burden the notation with specifications which have only potential interest. Since they have not received empirical support in our analysis, they would not be considered in what follows.
} 
Table 2: Empirical Literature

\begin{tabular}{|c|c|c|c|c|c|}
\hline Author & Variables & Period & Markets Included & Method & Results \\
\hline $\begin{array}{l}\text { Baig and Goldfajth } \\
(1999)\end{array}$ & $\begin{array}{l}\text { Stock mar- } \\
\text { ket indices, } \\
\text { interest } \\
\text { rates, ex- } \\
\text { change } \\
\text { rates }\end{array}$ & $\begin{array}{l}1995-1998 \\
\text { (daily) }\end{array}$ & TH, MA, IN, KO & $\begin{array}{l}\text { Correlation } \\
\text { Analysis }\end{array}$ & $\begin{array}{l}\text { Cross market cor- } \\
\text { relation increases } \\
\text { during the crisis. } \\
\text { News affects } \\
\text { neighbors. }\end{array}$ \\
\hline $\begin{array}{l}\text { Forbes and Rigobon } \\
(2001)\end{array}$ & $\begin{array}{l}\text { Stock mar- } \\
\text { ket indices, } \\
\text { interest } \\
\text { rates }\end{array}$ & $\begin{array}{l}\begin{array}{l}\text { 1996-1998 } \\
\text { (daily) }\end{array}\end{array}$ & $\begin{array}{l}\text { HK, IN, KO, MA, } \\
\text { SI, TA, TH }\end{array}$ & $\begin{array}{l}\text { Correlation } \\
\text { Analysis (het- } \\
\text { eroskedasticity } \\
\text { correction) }\end{array}$ & $\begin{array}{l}\text { No contagion, } \\
\text { only interdepen- } \\
\text { dence between } \\
\text { markets. No } \\
\text { increase in corre- } \\
\text { lation, assuming } \\
\text { that HK is the } \\
\text { dominant market. }\end{array}$ \\
\hline In et al. (2001) & $\begin{array}{l}\text { Stock mar- } \\
\text { ket indices }\end{array}$ & $\begin{array}{l}\text { 1997-1998 } \\
\text { (daily) }\end{array}$ & $\mathrm{HK}, \mathrm{KO}, \mathrm{TH}$ & $\begin{array}{l}\text { VAR- } \\
\text { EGARCH } \\
\text { (variance) }\end{array}$ & $\begin{array}{l}\text { Reciprocal volatil- } \\
\text { ity transmission } \\
\text { between } \mathrm{HK} \text { and } \\
\mathrm{KO} \text {, unidirectional } \\
\text { volatility trans- } \\
\text { mission from KO } \\
\text { to } \mathrm{TH} \text {. HK has a } \\
\text { primary role. }\end{array}$ \\
\hline $\begin{array}{l}\text { Fernandez-Izquierdo } \\
\text { and Lafuente (2004) }\end{array}$ & $\begin{array}{l}\text { Stock mar- } \\
\text { ket indices }\end{array}$ & $\begin{array}{l}1997-2001 \\
\text { (daily) }\end{array}$ & $\mathrm{HK}, \mathrm{SI}, \mathrm{KO}$ & $\begin{array}{ll}\begin{array}{l}\text { Factor } \\
\text { ysis, }\end{array} \text { Anal- } \\
\text { GARCH- } \\
\text { (bivariate } \\
\text { variance) }\end{array}$ & $\begin{array}{l}\text { Leverage effect } \\
\text { existence that is } \\
\text { not only due to } \\
\text { negative shocks } \\
\text { in the market but } \\
\text { also to shocks in } \\
\text { foreign markets. }\end{array}$ \\
\hline $\begin{array}{l}\text { Gallo and Otranto } \\
(2007)\end{array}$ & $\begin{array}{l}\text { Stock mar- } \\
\text { ket indices }\end{array}$ & $\begin{array}{l}\text { 1997-2001 } \\
\text { (weekly) }\end{array}$ & $\mathrm{HK}, \mathrm{KO}, \mathrm{MA}, \mathrm{SI}$ & $\begin{array}{l}\text { Bivariate Multi } \\
\text { Chain Markov } \\
\text { Switching } \\
\text { Model (mean) }\end{array}$ & $\begin{array}{l}\text { Assuming HK } \\
\text { dominant, HK has } \\
\text { a contagious effect } \\
\text { on KO and TH, } \\
\text { interdependence } \\
\text { between HK and } \\
\text { MA. }\end{array}$ \\
\hline Forbes (2004) & $\begin{array}{l}\text { Stock mar- } \\
\text { ket indices }\end{array}$ & $\begin{array}{l}1996-1998 \\
\text { (daily) }\end{array}$ & $\begin{array}{l}\text { HK, IN, KO, MA, } \\
\text { SI, TA, TH }\end{array}$ & $\begin{array}{l}\text { Probit Models } \\
\text { (mean) }\end{array}$ & $\begin{array}{l}\text { Trade links are } \\
\text { the most impor- } \\
\text { tant transmission } \\
\text { mechanism. }\end{array}$ \\
\hline $\begin{array}{l}\text { Kaminsky and Reinhart } \\
\text { (1999) }\end{array}$ & $\begin{array}{l}\text { Exchange } \\
\text { rates, li- } \\
\text { abilities, } \\
\text { stock prices, } \\
\text { mutual fund } \\
\text { holdings, } \\
\text { exports }\end{array}$ & $\begin{array}{l}\text { 1970-1998 } \\
\text { (monthly) }\end{array}$ & TH, MA, IN & $\begin{array}{l}\text { Probit Models } \\
\text { (mean) }\end{array}$ & $\begin{array}{l}\text { Probability of a } \\
\text { crisis increases } \\
\text { when more crises } \\
\text { occur in other } \\
\text { countries, espe- } \\
\text { cially in the same } \\
\text { geographical area. }\end{array}$ \\
\hline
\end{tabular}

Note: We report only the East Asian markets relevant for our analysis, that is: IN (Indonesia), HK (Hong Kong), KO (Korea), MA (Malaysia), SI (Singapore), TA (Taiwan), TH (Thailand). Other markets may have been considered in the corresponding studies but are not mentioned here. 
below, we chose a dummy during the crisis period which we identified with July 1 , 1997 to December 31, 1998, labelled $D C_{t}$ (other periods were adopted but provided less clear cut results) and a dummy for the period after the crisis (from Jan. 1, 1999 on), labelled $P C_{t}$;

3. interaction terms between daily ranges of all markets and $D C_{t-1}$ to accommodate the possibility of changing links during the crisis;

4. asymmetric effects in which the impact from own lagged volatility is split into two terms according to whether the lagged market returns are negative, respectively, positive (corresponding to dummy variables $D_{r_{i, t-1}<0}$, respectively, $D_{r_{i, t-1}>0}$ );

5. an interaction between $D C_{t-1}$ and the asymmetric effects.

The general model adopted in this context is the following

$$
\begin{aligned}
\mu_{i, t} & =\omega_{i}+\beta_{i} \mu_{i, t-1}+\alpha_{i, i}^{-} h l_{i, t-1} D_{r_{i, t-1}<0}+\alpha_{i, i}^{+} h l_{i, t-1} D_{r_{i, t-1}>0}+\sum_{i \neq j} \alpha_{i, j} h l_{j, t-1}+ \\
& +\gamma_{i, i}^{-} h l_{i, t-1} D C_{t-1} D_{r_{i, t-1}<0}+\gamma_{i, i}^{+} h l_{i, t-1} D C_{t-1} D_{r_{i, t-1}>0}+\sum_{i \neq j} \gamma_{i, j} h l_{j, t-1} D C_{t-1}+ \\
& +\delta_{i} D C_{t-1}+\lambda_{i} P C_{t-1}+\psi_{i} h l_{i, t-2}
\end{aligned}
$$

in which we have inserted links from other markets and the possibility that during a crisis or after it there is a discrete shift in the conditional expectation or that the value of the links changes during that period. The estimation results may signal the need for a more parsimonious specification, based either on zero restrictions or on the equality of the $\left(\alpha_{i, i}^{+}\right.$, $\left.\alpha_{i, i}^{-}\right)$or $\left(\gamma_{i, i}^{+}, \gamma_{i, i}^{-}\right)$coefficients. $^{2}$ Detailed coefficient estimation results are reported in two different tables (Tables 7 and 8) at the end of the paper, as they are not of direct interest in the discussion that follows. However, in Table 3 we summarize the selected specification for each market which are limited to the following four:

1. $\mathbf{E} \equiv \omega_{i}+\beta_{i} \mu_{i, t-1}+\sum_{j=1}^{n} \alpha_{i, j} h l_{j, t-1}\left(+\psi_{i} h l_{i, t-2}\right)$

2. $\mathbf{E}+\sum_{i=1}^{n} \gamma_{i, j} h l_{j, t-1} D C_{t-1}+\delta_{i} D C_{t-1}+\lambda_{i} P C_{t-1}$

3. $\mathbf{E}+\delta_{i} D C_{t-1}$

4. $\mathbf{E}+\sum_{i=1}^{n} \gamma_{i, j} h l_{j, t-1} D C_{t-1}$

The specification analysis includes diagnostics on the residuals $h l_{i, t} / \hat{\mu}_{i, t}$ in Table 4 where we set two different columns for the own market (base) specification and the models selected for each market. We report the values of likelihood functions, the Ljung Box test statistics for the null of no autocorrelation in the residuals and squared residuals. The estimated Gamma parameter $\hat{\phi}_{i}$ for the distribution of standardized residuals,

$$
\widehat{\phi_{i}^{-1}}=\frac{1}{T} \sum_{t=1}^{T}\left(\frac{h l_{i, t}}{\hat{\mu}_{i, t}}-1\right)^{2},
$$

turns out to be fairly similar across markets (between 3.5 and 6.5 with many around 4.5). The last row reports the test statistic of whether coefficients on any link across markets can be constrained to zero (labelled no spillover).

The results can be summarized as follows:

\footnotetext{
${ }^{2}$ Additional results and the detailed method of selection are available upon request.
} 


\begin{tabular}{|l|c|c|c|c|c|c|c|c|}
\hline & HK & IN & KO & MA & PH & SI & TA & TH \\
\hline Other markets & $\times$ & $\times$ & $\times$ & $\times$ & $\times$ & $\times$ & $\times$ & $\times$ \\
\hline Other markets during crisis & & $\times$ & $\times$ & & & & $\times$ & \\
\hline Own asymmetric effects & & & $\times$ & & & & $\times$ & \\
\hline Own asymmetries during crisis & $\times$ & & & & & $\times$ & $\times$ & $\times$ \\
\hline Shift during crisis & & $\times$ & $\times$ & $\times$ & $\times$ & & & \\
\hline Shift after crisis & & $\times$ & $\times$ & & & & & \\
\hline Lag 2 & & & & $\times$ & & $\times$ & & $\times$ \\
\hline
\end{tabular}

Table 3: Summary of the selected specification for each market. A cross $(\times)$ indicates the presence of significant additional links relative to the own market (base) specification.

- the general model (interactions with other markets, extra interactions during crisis, shifts during and after crisis) receives support only for two markets (Indonesia and Korea), at the other end of the spectrum the presence of extra interactions and shifts are dismissed in three markets (Hong Kong, Singapore and Thailand). In the middle we have no shifts but extra interactions in Taiwan and a shift during the crisis but no extra interactions for Malaysia and the Philippines;

- the shift after the crisis therefore gets empirical support for Indonesia and Korea. The same markets and Malaysia and the Philippines exhibit a shift in the expectation captured during the crisis. As for the others, note that there may be some comovements with the other markets which capture a 'common' shift: as a matter of fact, if one were to include the crisis dummy $\left(D C_{t-1}\right)$ in the base specification, the coefficient would turn out to be significant (but the same does not hold true for the post-crisis dummy);

- the scattered problems in residual diagnostics in the base models are generally disappear in the selected extended models. Beside this evidence, a formal null hypothesis of zero coefficients on all links in the retained specification gets strongly rejected. Hence the presence of dynamic interactions in various forms is relevant.

\section{A Look at the Spillovers within the MEM}

\subsection{Model Forecasts}

The general model can be detailed as follows, allowing for the possibility of a second (own) lag in the estimated MEM. We have

$$
\begin{aligned}
\left(\begin{array}{c}
\mu_{1, t} \\
\vdots \\
\mu_{n, t}
\end{array}\right)= & \left(\begin{array}{c}
\omega_{1} \\
\vdots \\
\omega_{n}
\end{array}\right)+\left(\begin{array}{c}
\delta_{1} \\
\vdots \\
\delta_{n}
\end{array}\right) D C_{t-1}+\left(\begin{array}{c}
\lambda_{1} \\
\vdots \\
\lambda_{n}
\end{array}\right) P C_{t-1}+\left(\begin{array}{ccc}
\beta_{1} & \cdots & 0 \\
\vdots & \ddots & \vdots \\
0 & \cdots & \beta_{n}
\end{array}\right)\left(\begin{array}{c}
\mu_{1, t-1} \\
\vdots \\
\mu_{n, t-1}
\end{array}\right) \\
+ & \left(\begin{array}{ccc}
\alpha_{1,1} & \cdots & \alpha_{1, n} \\
\vdots & \ddots & \vdots \\
\alpha_{n, 1} & \cdots & \alpha_{n, n}
\end{array}\right)\left(\begin{array}{c}
h l_{1, t-1} \\
\vdots \\
h l_{n, t-1}
\end{array}\right)+\left(\begin{array}{ccc}
\gamma_{1,1} & \cdots & \gamma_{1, n} \\
\vdots & \ddots & \vdots \\
\gamma_{n, 1} & \cdots & \gamma_{n, n}
\end{array}\right)\left(\begin{array}{c}
h l_{1, t-1} D C_{t-1} \\
\vdots \\
h l_{n, t-1} D C_{t-1}
\end{array}\right)
\end{aligned}
$$




$$
+\left(\begin{array}{ccc}
\psi_{1} & \cdots & 0 \\
\vdots & \ddots & \vdots \\
0 & \cdots & \psi_{n}
\end{array}\right)\left(\begin{array}{c}
h l_{1, t-2} \\
\vdots \\
h l_{n, t-2}
\end{array}\right)
$$

This can be written in a compact form conditional on the information available at time $t$ as

$$
\boldsymbol{\mu}_{t+1}=\boldsymbol{\omega}^{*}+\boldsymbol{\delta} D C_{t}+\boldsymbol{\lambda} P C_{t}+\mathbf{B} \boldsymbol{\mu}_{t}+\mathbf{A}^{*} \mathbf{h} \mathbf{l}_{t}+\boldsymbol{\Gamma} \mathbf{h} \mathbf{l}_{t} D C_{t}+\boldsymbol{A}_{2} \mathbf{h l}_{t-1}
$$

with $D C_{t}$ assuming value 1 if $t \in\{$ Jul. 2, 1997, Dec. 31, 1998\} and zero otherwise and $P C_{t}$ assuming value 1 if $t \in\{$ Jan. 1, 1999, Oct. 3, 2006 $\}$ and zero otherwise.

Moving further steps ahead, $\mathbf{h l}_{t+\tau}, \tau>0$ is not known and needs to be substituted with its corresponding conditional expectation $\boldsymbol{\mu}_{t+\tau}$. The dummies DC and PC are fixed to the value that they had in $t$. Hence,

$$
\begin{aligned}
\boldsymbol{\mu}_{t+2} & =\boldsymbol{\omega}^{*}+\boldsymbol{\delta} D C_{t}+\boldsymbol{\lambda} P C_{t}+\mathbf{B} \boldsymbol{\mu}_{t+1}+\mathbf{A}^{*} \boldsymbol{\mu}_{t+1}+\boldsymbol{\Gamma} \boldsymbol{\mu}_{t+1} D C_{t}+\boldsymbol{A}_{2} \mathbf{h} \mathbf{l}_{t} \\
& =\boldsymbol{\omega}^{*}+\boldsymbol{\delta} D C_{t}+\boldsymbol{\lambda} P C_{t}+\left(\mathbf{B}+\mathbf{A}^{*}+\boldsymbol{\Gamma} D C_{t}\right) \boldsymbol{\mu}_{t+1}+\boldsymbol{A}_{2} \mathbf{h l}_{t}
\end{aligned}
$$

and, then, for $\tau>2$

$$
\begin{aligned}
\boldsymbol{\mu}_{t+\tau} & =\boldsymbol{\omega}^{*}+\boldsymbol{\delta} D C_{t}+\boldsymbol{\lambda} P C_{t}+\left(\mathbf{B}+\mathbf{A}^{*}+\boldsymbol{\Gamma} D C_{t}\right) \boldsymbol{\mu}_{t+\tau-1}+\boldsymbol{A}_{2} \boldsymbol{\mu}_{t+\tau-2} \\
& =\boldsymbol{\omega}+\mathbf{A}_{1} \boldsymbol{\mu}_{t+\tau-1}+\mathbf{A}_{2} \boldsymbol{\mu}_{t+\tau-2}
\end{aligned}
$$

which can be solved recursively for any horizon $\tau$. For notational convenience, as customary in Vector Autoregressive models, it is possible to write the system (4) by stacking its elements to get the equivalent of a $\operatorname{VAR}(1)$, namely,

$$
\begin{aligned}
\left(\begin{array}{c}
\boldsymbol{\mu}_{t+\tau} \\
\boldsymbol{\mu}_{t+\tau-1}
\end{array}\right) & =\left(\begin{array}{c}
\boldsymbol{\omega} \\
\mathbf{0}
\end{array}\right)+\left(\begin{array}{cc}
\mathbf{A}_{1} & \mathbf{A}_{2} \\
\mathbf{I} & \mathbf{0}
\end{array}\right)\left(\begin{array}{l}
\boldsymbol{\mu}_{t+\tau-1} \\
\boldsymbol{\mu}_{t+\tau-2}
\end{array}\right) \\
\tilde{\boldsymbol{\mu}}_{t+\tau} & =\boldsymbol{\omega}+\mathbf{A} \tilde{\boldsymbol{\mu}}_{t+\tau-1}
\end{aligned}
$$

This will also allow us to study the properties of the system as matrix A rules its dynamics: Table 5 reports the eight largest eigenvalues of the matrices with the extra interactions (for those models which exhibited significant such links) and without. It is interesting to note that the crisis period induces some complex roots with corresponding cyclicality of the forecasts, with minor differences between the two sets of periods.

As customary, we will have

$$
\begin{aligned}
\tilde{\boldsymbol{\mu}}_{t+\tau} & =\boldsymbol{\omega}+\mathbf{A} \tilde{\boldsymbol{\mu}}_{t+\tau-1}=\boldsymbol{\omega}+\mathbf{A}\left(\boldsymbol{\omega}+\mathbf{A} \tilde{\boldsymbol{\mu}}_{t+\tau-2}\right)=(\boldsymbol{I}+\mathbf{A}) \boldsymbol{\omega}+\mathbf{A}^{2} \tilde{\boldsymbol{\mu}}_{t+\tau-2} \\
& =\left(\boldsymbol{I}+\mathbf{A}+\ldots+\mathbf{A}^{\tau-3}\right) \boldsymbol{\omega}+\mathbf{A}^{\tau-2} \tilde{\boldsymbol{\mu}}_{t+2}, \forall \tau>2 \\
\lim _{\tau \rightarrow \infty} \tilde{\boldsymbol{\mu}}_{t+\tau} & =(\mathbf{I}-\mathbf{A})^{-1} \boldsymbol{\omega}
\end{aligned}
$$



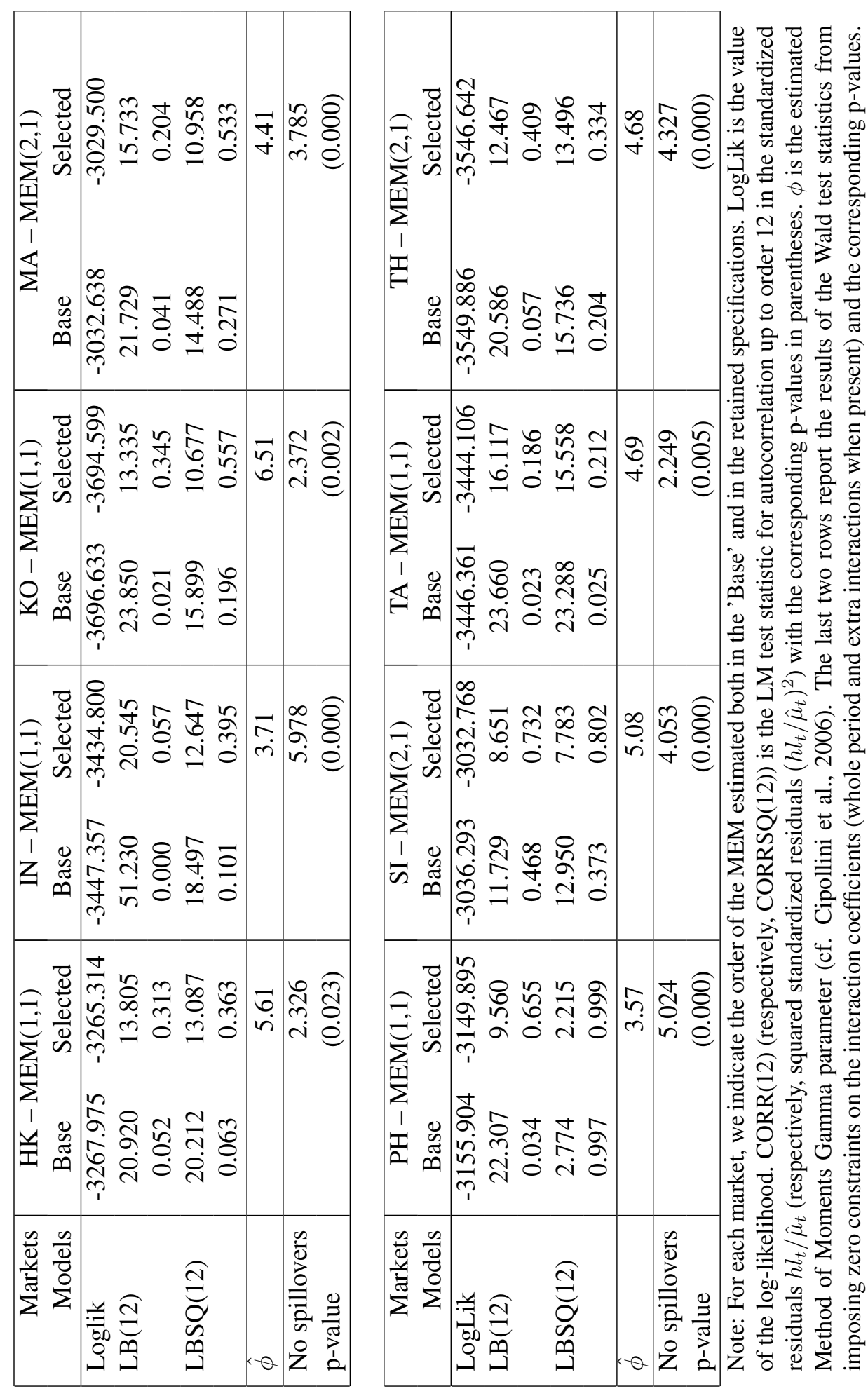

Table 4: Model Diagnostics 


\begin{tabular}{|c|c|}
\hline Jul. 2, 1997-Dec. 31, 1998 & Other periods \\
\hline 0.9819 & 0.9843 \\
0.9345 & 0.9567 \\
$0.9204+0.0157 \mathrm{i}$ & 0.9341 \\
$0.9204-0.0157 \mathrm{i}$ & 0.9193 \\
$0.9119+0.0213 \mathrm{i}$ & 0.9099 \\
$0.9119-0.0213 \mathrm{i}$ & 0.8857 \\
0.7522 & 0.7457 \\
0.6545 & 0.6317 \\
\hline
\end{tabular}

Table 5: Largest eigenvalues for the A Matrix.

The average (long run) forecasts using the coefficients estimated in the three possible subperiods are reported in Table 6. By and large, the values show a permanent surge in volatility (a high level in the crisis period and a level in the final period higher than the first): an explanation is the effects of the aftermath of the crisis, but also an increased intensity of exchanges within markets and across. The only exception seems to be Taiwan which shows a progressive increase in the average level of volatility. We also reported the average value of the volatility index VIX (derived from the S\&P500) in order to compare our estimates to a prevailing level of volatility in the US market. The big surge in the Asian countries volatility during the crisis is apparent (especially for Indonesia, Korea, Malaysia, and Thailand).

\begin{tabular}{|c|ccc|}
\hline Market & Pre-crisis & Crisis & Post-crisis \\
\hline HK & 19.17 & 38.44 & 23.70 \\
IN & 16.84 & 49.22 & 27.98 \\
KO & 23.24 & 45.97 & 34.59 \\
MA & 16.16 & 48.10 & 19.12 \\
PH & 19.47 & 34.38 & 20.82 \\
SI & 15.87 & 32.15 & 20.49 \\
TA & 24.49 & 26.70 & 28.93 \\
TH & 25.09 & 45.27 & 28.61 \\
\hline VIX & 16.44 & 25.33 & 20.76 \\
\hline
\end{tabular}

Table 6: Estimated average (long run) volatility forecast for three sub-periods: Precrisis (07/18/1995-06/30/1997); Crisis (07/02/1997-12/31/1998); Post-crisis (1/1/1999_ 10/03/2006). Last row is average VIX for the same periods.

Finally, we perform volatility dynamic forecasting exercises to see how the MEM allows us to investigate the evolution of two episodes. The first is October 1997. Starting from October 1, we predict from 1 to 90 periods ahead, then move the starting date by a (variable) number of days and repeat the same exercise. The result is a superposition of multiperiod forecast profiles which can be represented graphically as in Figure 3. The height of the crisis (between Oct. 20 and Oct. 24, 1997) is marked by vertical lines. The analysis shows the difference in response by different markets through the multivariate 
dynamic model. For Indonesia, Korea, Malaysia and Thailand we have, again, a humpshaped forecasting profile showing the delay by which these markets responded to the crisis. Such a pattern is absent from the analysis of September, 2001 (around 9/11), where by the responses are much more limited and do not seem to involve major interactions (see Figure 4, where vertical lines are between Sep. 10 and Sep. 14, 2001).

\subsection{The Nonlinear Shock Propagation}

The estimated MEMs for each market assembled into a system lend themselves to being used to mimic how shock originating in one market propagate through time. The idea is similar in spirit to the impulse response functions described in Engle et al.(1990) where recursive equations where designed to evaluate the way a news hitting one market would propagate to the volatility of all markets (for alternative ways to define impulse response functions in a nonlinear context see Koop et al., 1996 and Gallant et al., 1993). In this context, we prefer to analyze volatility shock propagation in what could be seen as a sort of scenario analysis.

In fact, let us consider, again, the system (6)

$$
\left(\begin{array}{c}
h l_{1, t} \\
\vdots \\
h l_{n, t}
\end{array}\right)=\left(\begin{array}{c}
\mu_{1, t} \\
\vdots \\
\mu_{n, t}
\end{array}\right) \odot\left(\begin{array}{c}
\epsilon_{1, t} \\
\vdots \\
\epsilon_{n, t}
\end{array}\right) \leftrightarrow \mathbf{h l}_{\mathbf{t}}=\boldsymbol{\mu}_{\mathbf{t}} \odot \boldsymbol{\epsilon}_{\mathbf{t}}
$$

where the innovation term $\epsilon_{t}$ is a jointly multivariate i.i.d. process with unit mean and variance covariance matrix $\Sigma$. In the equation-by-equation estimation procedure adopted here we have implicitly assumed that such a matrix is diagonal; for a discussion of the difficulties in estimating a vector MEM with a full $\Sigma$, we refer to Cipollini et al. (2006). We interpret $\boldsymbol{\mu}_{t}$ as the expectation of $\mathbf{h l}_{\mathbf{t}}$ conditional on $\boldsymbol{\epsilon}_{t}$ being equal to the unit vector 1 , that is,

$$
\boldsymbol{\mu}_{t}=E\left(\mathbf{h l}_{\mathbf{t}} \mid \boldsymbol{\epsilon}_{\mathbf{t}}=\mathbf{1}\right) .
$$

We will consider the forecasting setup described before as providing a baseline solution starting at time $t$ against which we will contrast a different solution in which the $\epsilon_{t}$ vector is set at a value bigger than the unit vector. We will have, therefore,

$$
\boldsymbol{\mu}_{t}^{*}=E\left(\mathbf{h l}_{\mathbf{t}} \mid \boldsymbol{\epsilon}_{\mathbf{t}}=\mathbf{1}+\mathbf{s}\right)
$$

for a generic vector $\mathbf{s}$. Let us consider the $i$-th market and assume that $s_{i}=\sigma_{i}$, the unconditional standard deviation of the distribution of $\epsilon_{i t}$. We may want to consider the other elements of $\mathbf{s}$ equal to zero (a procedure which is reminiscent of Gallant et al., 1993) or we can exploit the information about the contemporaneous covariation in $\epsilon_{t}$ choosing the other terms $j \neq i$ to be the conditional expectation of $\epsilon_{j, t}$ conditional on setting $\epsilon_{i, t}$ equal to $1+\sigma_{i}$. In terms of linear projections, a convenient expression is

$$
E\left(\epsilon_{j, t} \mid \epsilon_{i, t}=1+\sigma_{i}\right)=1+\frac{\sigma_{i, j}}{\sigma_{i}^{2}}
$$

We show two graphs (Figure 5 and Figure 6) where the originating shock comes from Thailand, respectively, Hong Kong in the historical market conditions of July,2, 1997 
and October, 22, 1997. The first figure shows that the shock propagates, according to the estimation results, only to Hong Kong (with a high persistence which puts the Hong Kong response above the Thai response after 22 periods), the other responses being very feeble. The second figure shows the leading role of Hong Kong in that the responses are generally stronger with some hump-shaped profiles (Korea, Indonesia, Malaysia and Thailand) exhibiting the peak in the response after 10 days (Indonesia), 15 days (Malaysia and Korea) and 28 days (Thailand).

\section{Concluding Remarks}

In this paper, we analyze the interdependence and dynamic transmission mechanisms of volatility across East Asian markets during 1990-2006 with a focus on the Asian crisis period (1997-1998). We use a multivariate extension of the Multiplicative Error Model, adapted for the analysis of more than one market and for the dynamic interaction between markets. The interest of our MEM-based approach to investigate the mechanisms of volatility spillovers from one market to another lies in the possibility of enlarging the list of predetermined variables for the scale factor to include volatility proxies of other markets. The same procedure can be repeated for more than one market, with the result of obtaining a fully interdependent dynamic model.

Using this approach, the spillovers existence can be easily tested and their direction and intensity can be specified. The empirical analysis is carried out with the estimated models selected for each market and nonlinear impulse response functions and forecasting profiles are developed.

Concerning East Asian markets we find no evidence of independent markets while several interdependence relationships can be stressed (for example between Hong Kong and Korea). As expected, Hong Kong turns out to be the most important market among the 8 considered while Taiwan seems to have suffered quite limited effects from the crisis. Impulse response functions and multiperiod forecast profiles suggest a build-up in the spillover effects. For the impulse response functions we present results from two markets that represent the originating shock: Thailand (July 2, 1997) and Hong Kong (October $22,1997)$. The results highlight that the shock from Thailand propagated mainly to Hong Kong; also, we show that Hong Kong had a leading role in the crisis in that the responses are generally stronger with some hump-shaped profiles (Korea, Indonesia, Malaysia and Thailand) exhibiting the peak in the response with some delay (Indonesia, Malaysia, Korea and Thailand).

Finally, we perform two forecasting exercises (October, 1997 and September, 2001). The analysis shows for Indonesia, Korea, Malaysia and Thailand a hump-shaped forecasting profile representing the delay by which these markets responded to the crisis. Such a pattern is absent from the analysis of the September, 2001, where the responses are of a much smaller size. 

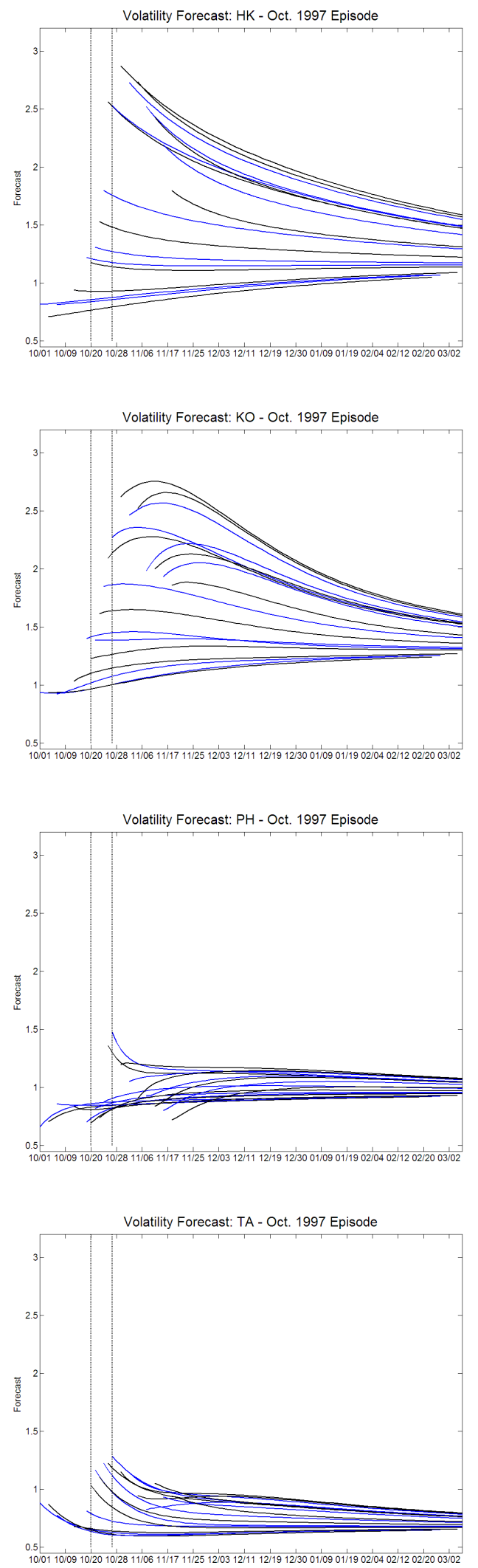
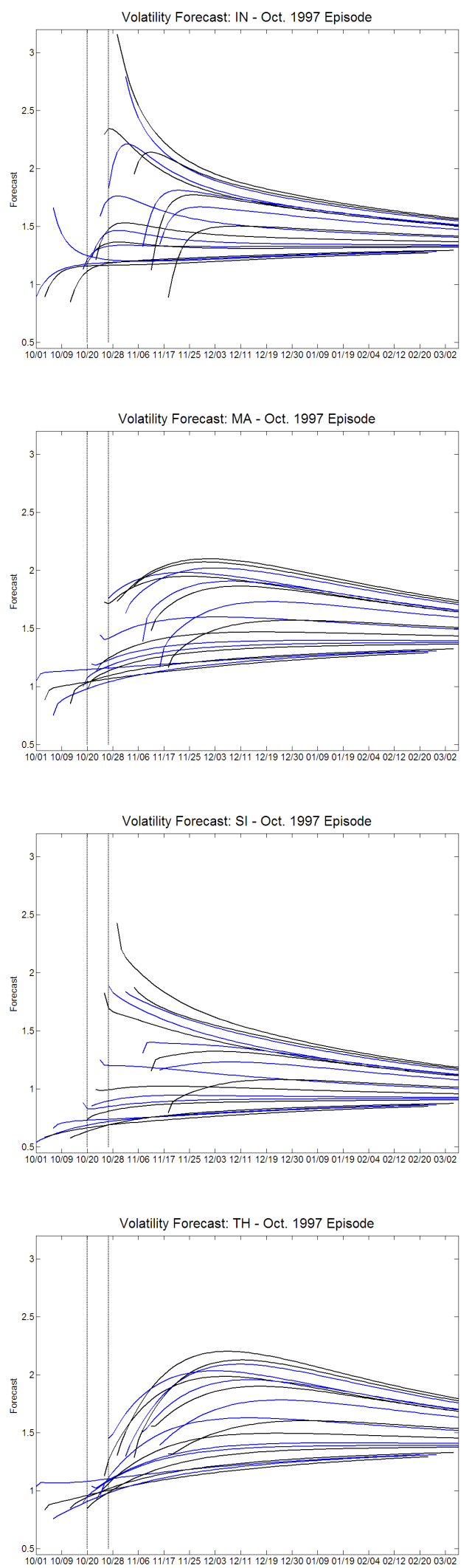

Figure 3: Dynamic Volatility Forecasts. For the HK, IN, KO, MA, PH, SI, TA, TH markets, each line depicts the system forecasts computed according to expression (5) starting from Oct. 1, 1997 and progressively moving the initial condition ahead (keeping the asymmetric effects where appropriate). The vertical lines isolate the period between Oct. 20 and Oct. 24, 1997 as the week when the crisis of Oct. 1997 originated. 

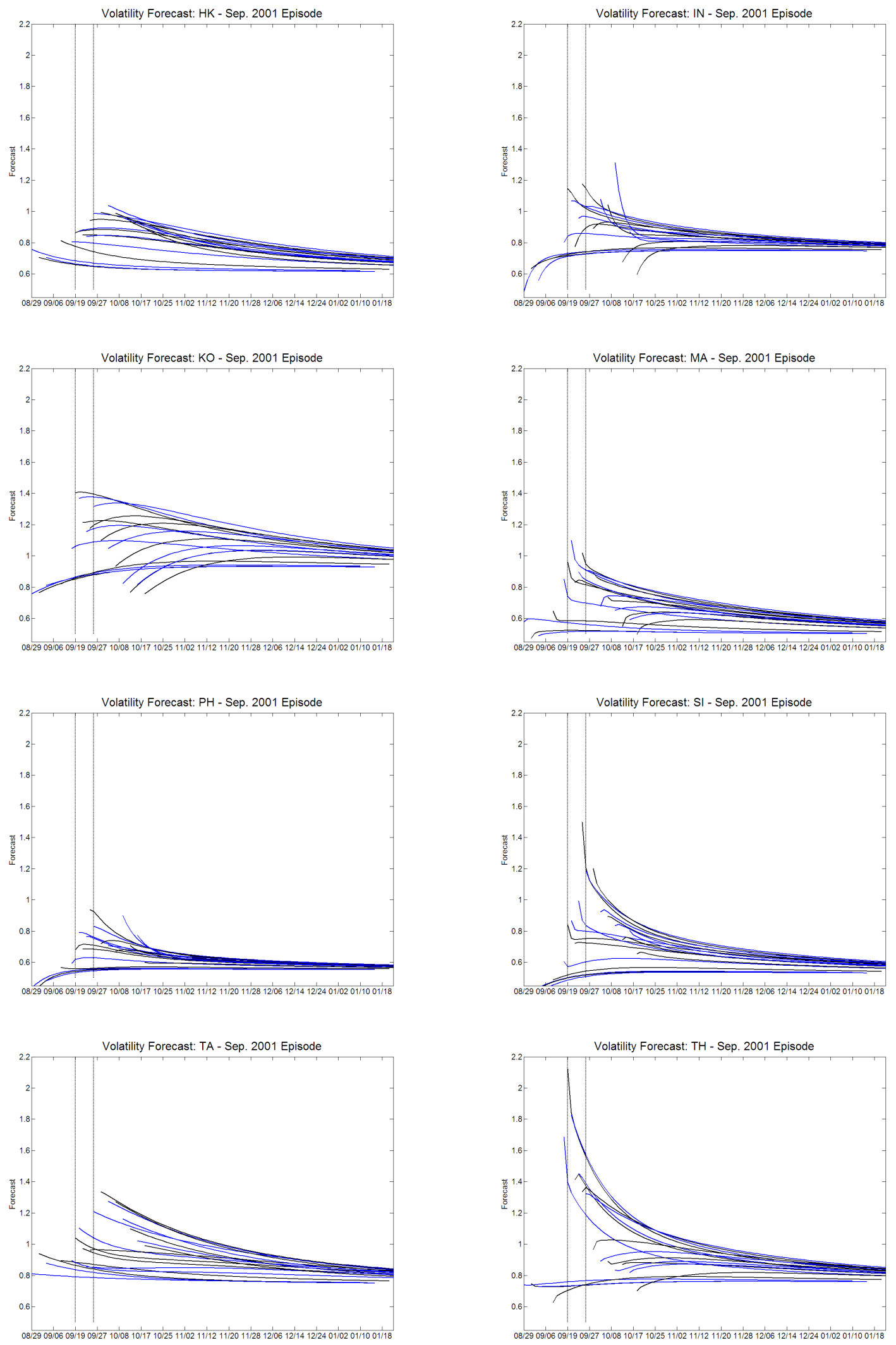

Figure 4: Dynamic Volatility Forecasts. For the HK, IN, KO, MA, PH, SI, TA, TH markets, each line depicts the system forecasts computed according to expression (5) starting from Aug. 27, 2001 and progressively moving the initial condition ahead (keeping the asymmetric effects where appropriate). The vertical lines isolate the period between Sep. 10 and Sep. 14, 2001 as the week of the terrorist attacks in the USA. 


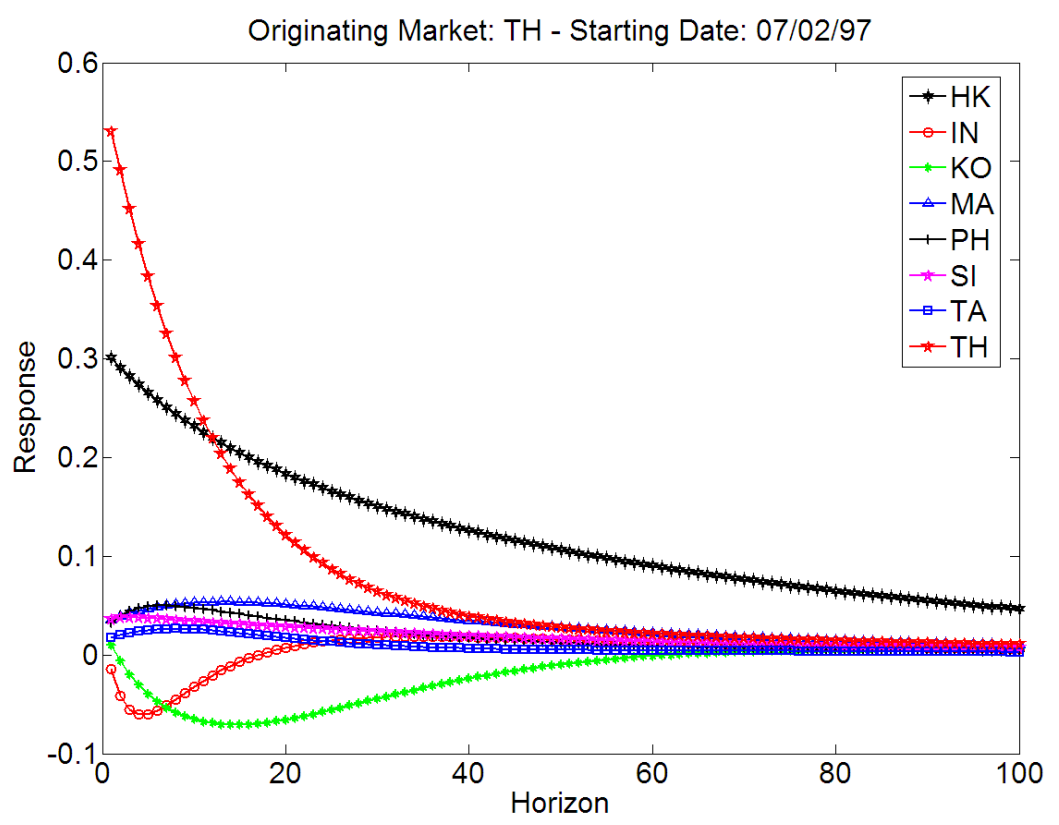

Figure 5: Impulse Response Functions. Each line shows markets response to the shock originating in Thailand (July, 2, 1997).

\section{References}

Alizadeh S., M. W. Brandt and F. X. Diebold (2002), Range-Based Estimation of Stochastic Volatility Models, The Journal of Finance, 57 (3) , 10471091

Baig T. and Goldfajn, I. (1999), Financial Market Contagion in the Asian Crisis, IMF Staff Papers 46, 167- 195.

Caramazza F., L.A. Ricci and R. Salgado (2004), International Financial Contagion in Currency Crises, Journal of International Money and Finance Volume, 23, Issue 1, $51-70$

Cipollini F., R.F. Engle and G.M. Gallo (2006), Vector Multiplicative Error Models: Representation and Inference, NBER Working Paper, No. W12690

Classens S. and K. Forbes (eds.) (2001), International and Financial Contagion, Kluwer Academic Publishers, Boston, MA.

Diebold F.X. and K. Yilmaz (2008), Measuring Financial Asset Return and Volatility Spillovers, with Application to Global Equity Markets, NBER Working Paper, No. W13811

Edwards S. (1998), Interest Rate Volatility, Capital Control and Contagion, NBER Working Paper, 6756. 


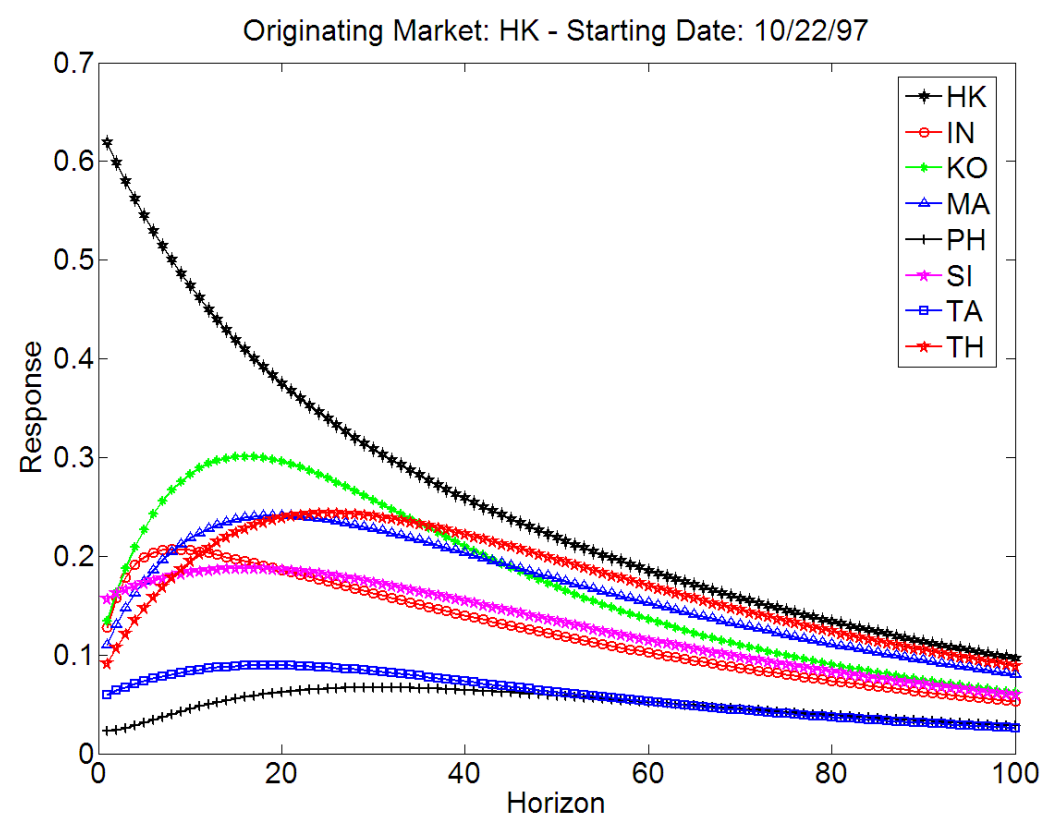

Figure 6: Impulse Response Functions. Each line shows markets response to the shock originating in Hong Kong (Oct., 22, 1997).

Edwards S., and R. Susmel (2001), Volatility Dependence and Contagion in Emerging Equity Markets, Journal of Development Economics, 66, 505-532.

Edwards S., and R. Susmel (2003) Interest Rate Volatility in Emerging Markets, The Review of Economics and Statistics, 85, 328-348.

Eichengreen B., A. Rose and C. Wyplosz (1996), Contagious Currency Crises: Final Test, Scandinavian Journal of Economics, 38, 463-494.

Engle R.F. (2002), New Frontiers for ARCH models, Journal of Applied Econometrics, $17,425-446$.

Engle R.F. and G.M.Gallo (2006), A Multiple Indicators Model for Volatility using Intra-daily Data, Journal of Econometrics, 131, 3-27.

Engle R.F., T. Ito, and W. Lin (1990), Meteor Showers or Heat Waves? Heteroskedastic Intra-daily Volatility in the Foreign Exchange Market, Econometrica,Vol. 58, No. $3,525-542$

Fernandez-Izquierdo A. and J. A. Lafuente (2004), International Transmission of Stock Exchange Volatility: Empirical Evidence from the Asian Crisis, Global Finance Journal 15,125137

Fleming M.J. and J.A. Lopez (1999), Heat Waves, Meteor Showers and Trading Volume: An Analysis of Volatility Spillovers in the U.S. Treasury Market, FED of New York, Staff Reports. 
Forbes K. (2004), The Asian Flu and the Russian Virus: Firm-level Evidence on How Crises are Transmitted Internationally, Journal of International Economics, 63, 59-92.

Forbes K. and R. Rigobon (2001) Measuring Contagion: Conceptual and Empirical Issues, in: Claessens, S., Forbes, K. (eds.), International Financial Contagion, Kluwer Academic Publishers, Boston, 43-66.

Forbes K. and R. Rigobon (2002), No Contagion, Only Interdependence: Measuring Stock Market Comovements, Journal of Finance, 57, 2223- 2261.

Fratzscher M. (2003), On Currency Crises and Contagion, International Journal of Finance and Economics, 8, 109:129.

Gallant A.R., P. E. Rossi and G. Tauchen (1993), Nonlinear Dynamic Structures, Econometrica, Vol. 61, No. 4, 871-907

Gallo G.M. and E. Otranto (2007), Volatility Transmission Across Markets: A MultiChain Markov Switching Model, Applied Financial Economics, vol. 17(8), 659-670

Hamilton J.D. (1994), Time Series Analysis, Princeton University Press, Princeton.

Hardy D.C. and C. Pazarbaşoĝlu (1998), Leading Indicators of Banking Crises: Was Asia Different?, IMF Working Papers, 91

In F., S. Kim, J.H. Yoon and C. Viney (2001), Dynamic Interdependence and Volatility Transmissions of Asian Stock Markets: Evidence from the Asian Crisis. International Review of Financial Analysis 10, pp. 8796

Kaminsky G.L. (1999), Currency and Banking Crises: the Early Warnings of Distress, FED International Finance Discussion Papers 629.

Kaminsky G. and C.M. Reinhart (1999), The Twin Crises: the Causes of Banking and Balance-of-Payments Problems, American Economic Review 89, 473-500, (1999)

Kaminsky G.L., S. Lizondo, and C. M. Reinhart (1998) Leading Indicators of Currency Crises, IMF Staff Paper, 45, 11-48.

Koop G., M. H. Pesaran and S. M. Potter (1996), Impulse Response Analysis in Nonlinear Multivariate Models, Journal of Econometrics, 74, 19-147

Pericoli M. and M. Sbracia (2003), A Primer on Financial Contagion, Journal of Economic Surveys, 17, 571-608.

Van Rijckeghem C., and B. Weder (2001), Sources of Contagion: Is It Finance or Trade?, Journal of International Economics, 54, 293-308. 


\begin{tabular}{|c|c|c|c|c|c|c|c|c|}
\hline \multirow{2}{*}{$\begin{array}{c}\text { Markets } \\
\text { Models }\end{array}$} & \multicolumn{2}{|c|}{ HK } & \multicolumn{2}{|c|}{ IN } & \multicolumn{2}{|c|}{$\mathrm{KO}$} & \multicolumn{2}{|c|}{ MA } \\
\hline & Base & Selected & Base & Selected & Base & Selected & Base & Selected \\
\hline$\omega$ & $\begin{array}{c}0.006 \\
(3.334)\end{array}$ & $\begin{array}{c}0.006 \\
(1.710)\end{array}$ & $\begin{array}{c}0.070 \\
(7.791)\end{array}$ & $\begin{array}{c}0.052 \\
(3.426)\end{array}$ & $\begin{array}{c}0.018 \\
(4.713)\end{array}$ & $\begin{array}{c}0.006 \\
(0.849)\end{array}$ & $\begin{array}{c}0.005 \\
(3.497)\end{array}$ & $\begin{array}{c}0.002 \\
(0.568)\end{array}$ \\
\hline$\mu_{t-1}$ & $\begin{array}{c}0.865 \\
(70.559)\end{array}$ & $\begin{array}{c}0.835 \\
(51.814)\end{array}$ & $\begin{array}{c}0.526 \\
(20.222)\end{array}$ & $\begin{array}{c}0.281 \\
(6.415)\end{array}$ & $\begin{array}{c}0.763 \\
(48.674)\end{array}$ & $\begin{array}{c}0.729 \\
(38.010)\end{array}$ & $\begin{array}{c}0.861 \\
(54.847)\end{array}$ & $\begin{array}{c}0.783 \\
(28.237)\end{array}$ \\
\hline$D C_{t-1}$ & & & & $\begin{array}{c}0.074 \\
(0.955)\end{array}$ & & $\begin{array}{c}0.064 \\
(2.041)\end{array}$ & & $\begin{array}{c}0.031 \\
(3.297)\end{array}$ \\
\hline$P C_{t-1}$ & & & & $\begin{array}{c}0.077 \\
(6.448)\end{array}$ & & $\begin{array}{c}0.014 \\
(3.109)\end{array}$ & & \\
\hline$H K_{t-1}$ & $\begin{array}{c}0.126 \\
(10.547)\end{array}$ & $\begin{array}{l}0.120 \\
(9.640)\end{array}$ & & $\begin{array}{c}0.005 \\
(0.218)\end{array}$ & & $\begin{array}{c}0.011 \\
(0.827)\end{array}$ & & $\begin{array}{c}0.036 \\
(4.048)\end{array}$ \\
\hline$H K_{t-1} D C_{t-1}$ & & & & $\begin{array}{l}0.067 \\
(0.882)\end{array}$ & & $\begin{array}{c}0.054 \\
(1.954)\end{array}$ & & \\
\hline$I N_{t-1}$ & & $\begin{array}{c}0.005 \\
(1.258)\end{array}$ & $\begin{array}{c}0.387 \\
(16.860)\end{array}$ & $\begin{array}{c}0.356 \\
(13.427)\end{array}$ & & $\begin{array}{l}0.006 \\
(0.656)\end{array}$ & & $\begin{array}{l}-0.001 \\
(-0.159)\end{array}$ \\
\hline$I N_{t-1} D C_{t-1}$ & & & & $\begin{array}{c}-0.055 \\
(-1.412)\end{array}$ & & $\begin{array}{c}-0.022 \\
(-1.382)\end{array}$ & & \\
\hline$K O_{t-1}$ & & $\begin{array}{c}0.004 \\
(0.996)\end{array}$ & & $\begin{array}{c}0.054 \\
(3.269)\end{array}$ & & & & $\begin{array}{c}0.002 \\
(0.364)\end{array}$ \\
\hline$K O_{t-1} D C_{t-1}$ & & & & $\begin{array}{c}-0.055 \\
(-1.412)\end{array}$ & & $\begin{array}{c}0.021 \\
(1.162)\end{array}$ & & \\
\hline$M A_{t-1}$ & & $\begin{array}{c}0.005 \\
(1.145)\end{array}$ & & $\begin{array}{c}0.038 \\
(2.031)\end{array}$ & & $\begin{array}{l}0.016 \\
(1.448)\end{array}$ & $\begin{array}{c}0.352 \\
(15.670)\end{array}$ & $\begin{array}{c}0.320 \\
(13.889)\end{array}$ \\
\hline$M A_{t-1} D C_{t-1}$ & & & & $\begin{array}{l}0.006 \\
(0.150)\end{array}$ & & $\begin{array}{c}-0.027 \\
(-1.868)\end{array}$ & & \\
\hline$\left.M A_{(} t-2\right)$ & & & & & & & $\begin{array}{l}-0.222 \\
(-8.220)\end{array}$ & $\begin{array}{l}-0.166 \\
(-5.565)\end{array}$ \\
\hline$P H_{t-1}$ & & $\begin{array}{c}0.001 \\
(0.220)\end{array}$ & & $\begin{array}{c}0.023 \\
(1.204)\end{array}$ & & $\begin{array}{c}-0.006 \\
(-0.630)\end{array}$ & & $\begin{array}{l}0.008 \\
(1.274)\end{array}$ \\
\hline$P H_{t-1} D C_{t-1}$ & & & & $\begin{array}{c}0.064 \\
(1.144)\end{array}$ & & $\begin{array}{l}0.019 \\
(0.800)\end{array}$ & & \\
\hline$S I_{t-1}$ & & $\begin{array}{c}0.009 \\
(1.256)\end{array}$ & & $\begin{array}{c}0.065 \\
(2.375)\end{array}$ & & $\begin{array}{c}0.014 \\
(0.957)\end{array}$ & & $\begin{array}{c}-0.004 \\
(-0.545)\end{array}$ \\
\hline $\begin{array}{l}S I_{t-1} D C_{t-1} \\
S I_{t-2}\end{array}$ & & & & $\begin{array}{l}0.081 \\
(1.068)\end{array}$ & & $\begin{array}{l}0.008 \\
(0.295)\end{array}$ & & \\
\hline$T A_{t-1}$ & & $\begin{array}{c}0.001 \\
(0.213)\end{array}$ & & $\begin{array}{c}-0.010 \\
(-0.718)\end{array}$ & & $\begin{array}{c}0.010 \\
(1.262)\end{array}$ & & $\begin{array}{c}0.000 \\
(0.042)\end{array}$ \\
\hline$T A_{t-1} D C_{t-1}$ & & & & $\begin{array}{c}0.113 \\
(1.713)\end{array}$ & & $\begin{array}{l}-0.055 \\
(-1.457)\end{array}$ & & \\
\hline$T H_{t-1}$ & & $\begin{array}{c}0.007 \\
(2.069)\end{array}$ & & $\begin{array}{c}0.040 \\
(2.666)\end{array}$ & & $\begin{array}{c}0.014 \\
(1.952)\end{array}$ & & 0.005 \\
\hline $\begin{array}{l}T H_{t-1} D C_{t-1} \\
T H_{t-2}\end{array}$ & & & & $\begin{array}{c}-0.129 \\
(-5.136)\end{array}$ & & $\begin{array}{c}-0.051 \\
(-3.217)\end{array}$ & & (1.186) \\
\hline$m k t_{t-1}^{+}$ & & & & & $\begin{array}{c}0.206 \\
(13.499)\end{array}$ & $\begin{array}{c}0.188 \\
(11.623)\end{array}$ & & \\
\hline$m k t_{t-1}^{-}$ & & & & & $\begin{array}{c}0.231 \\
(15.563)\end{array}$ & $\begin{array}{c}0.222 \\
(14.545)\end{array}$ & & \\
\hline$m k t_{t-1}^{+} D C_{t-1}$ & & $\begin{array}{c}-0.036 \\
(-2.672)\end{array}$ & & & & & & \\
\hline$m k t_{t-1}^{-} D C_{t-1}$ & & $\begin{array}{c}0.048 \\
(3.132)\end{array}$ & & & & & & \\
\hline
\end{tabular}

Table 7: Estimated Coefficient (t-stat in parenthesis) for HK, IN, KO, MA. Jul. 1995 Dec. 2006. 


\begin{tabular}{|c|c|c|c|c|c|c|c|c|}
\hline \multirow{2}{*}{$\begin{array}{l}\text { Markets } \\
\text { Models }\end{array}$} & \multicolumn{2}{|c|}{$\mathrm{PH}$} & \multicolumn{2}{|c|}{ SI } & \multicolumn{2}{|c|}{ TA } & \multicolumn{2}{|c|}{ TH } \\
\hline & Base & Selected & Base & Selected & Base & Selected & Base & Selected \\
\hline$\omega$ & $\begin{array}{c}0.049 \\
(6.545)\end{array}$ & $\begin{array}{c}0.081 \\
(5.786)\end{array}$ & $\begin{array}{c}0.007 \\
(3.799)\end{array}$ & $\begin{array}{c}0.000 \\
(0.015)\end{array}$ & $\begin{array}{c}0.024 \\
(5.662)\end{array}$ & $\begin{array}{c}0.021 \\
(3.465)\end{array}$ & $\begin{array}{c}0.014 \\
(4.171)\end{array}$ & $\begin{array}{c}0.020 \\
(2.967)\end{array}$ \\
\hline$\mu_{t-1}$ & $\begin{array}{c}0.695 \\
(24.538)\end{array}$ & $\begin{array}{c}0.522 \\
(11.659)\end{array}$ & $\begin{array}{c}0.854 \\
(44.347)\end{array}$ & $\begin{array}{c}0.766 \\
(26.224)\end{array}$ & $\begin{array}{c}0.800 \\
(51.001)\end{array}$ & $\begin{array}{c}0.789 \\
(44.500)\end{array}$ & $\begin{array}{c}0.841 \\
(47.584)\end{array}$ & $\begin{array}{c}0.746 \\
(25.427)\end{array}$ \\
\hline $\begin{array}{l}D C_{t-1} \\
P C_{t-1}\end{array}$ & & $\begin{array}{l}0.041 \\
2.789\end{array}$ & & & & & & \\
\hline$H K_{t-1}$ & & $\begin{array}{c}-0.012 \\
(-0.866)\end{array}$ & & $\begin{array}{c}0.020 \\
(2.309)\end{array}$ & & $\begin{array}{c}0.026 \\
(2.212)\end{array}$ & & $\begin{array}{c}0.027 \\
(1.959)\end{array}$ \\
\hline$H K_{t-1} D C_{t-1}$ & & & & & & $\begin{array}{l}-0.005 \\
(-0.249)\end{array}$ & & \\
\hline$I N_{t-1}$ & & $\begin{array}{c}0.015 \\
(1.472)\end{array}$ & & $\begin{array}{c}0.013 \\
(2.677)\end{array}$ & & $\begin{array}{c}0.000 \\
(0.012)\end{array}$ & & $\begin{array}{l}-0.008 \\
(-1.191)\end{array}$ \\
\hline$I N_{t-1} D C_{t-1}$ & & & & & & $\begin{array}{l}-0.005 \\
(-0.440)\end{array}$ & & \\
\hline$K O_{t-1}$ & & $\begin{array}{l}-0.023 \\
(-2.724)\end{array}$ & & $\begin{array}{c}0.007 \\
(1.546)\end{array}$ & & $\begin{array}{c}0.007 \\
(1.053)\end{array}$ & & $\begin{array}{c}0.015 \\
(2.000)\end{array}$ \\
\hline$K O_{t-1} D C_{t-1}$ & & & & & & $\begin{array}{c}0.011 \\
(1.108)\end{array}$ & & \\
\hline$M A_{t-1}$ & & $\begin{array}{c}0.030 \\
(1.985)\end{array}$ & & $\begin{array}{c}0.004 \\
(0.654)\end{array}$ & & $\begin{array}{c}0.001 \\
(0.059)\end{array}$ & & $\begin{array}{c}0.020 \\
(2.361)\end{array}$ \\
\hline$M A_{t-1} D C_{t-1}$ & & & & & & $\begin{array}{c}0.001 \\
(0.106)\end{array}$ & & \\
\hline$M A_{(}(t-2)$ & & & & & & & & \\
\hline$P H_{t-1}$ & $\begin{array}{c}0.224 \\
(9.086)\end{array}$ & $\begin{array}{c}0.235 \\
(11.112)\end{array}$ & & $\begin{array}{c}0.012 \\
(2.021)\end{array}$ & & $\begin{array}{l}-0.006 \\
(-0643)\end{array}$ & & 0.019 \\
\hline$P H_{t-1} D C_{t-1}$ & & & & & & $\begin{array}{c}0.043 \\
(2.402)\end{array}$ & & \\
\hline$S I_{t-1}$ & & $\begin{array}{c}0.057 \\
(2.971)\end{array}$ & $\begin{array}{c}0.333 \\
(13.111)\end{array}$ & $\begin{array}{c}0.283 \\
(11.801)\end{array}$ & & $\begin{array}{c}0.014 \\
(1.062)\end{array}$ & & $\begin{array}{c}0.015 \\
(1.111)\end{array}$ \\
\hline$S I_{t-1} D C_{t-1}$ & & & & & & $\begin{array}{l}-0.048 \\
(-2.502)\end{array}$ & & \\
\hline$S I_{t-2}$ & & & $\begin{array}{l}-0.200 \\
(-6.175)\end{array}$ & $\begin{array}{l}-0.140 \\
(-4.644)\end{array}$ & & & & \\
\hline$T A_{t-1}$ & & $\begin{array}{l}0.010 \\
(1.064)\end{array}$ & & $\begin{array}{c}0.012 \\
(2.689)\end{array}$ & & & & $\begin{array}{c}-0.011 \\
(-1.512)\end{array}$ \\
\hline$T A_{t-1} D C_{t-1}$ & & & & & & & & \\
\hline$T H_{t-1}$ & & $\begin{array}{c}0.025 \\
(2.612)\end{array}$ & & $\begin{array}{c}0.004 \\
(0.886)\end{array}$ & & $\begin{array}{c}-0.012 \\
(-2.229)\end{array}$ & $\begin{array}{c}0.276 \\
(11.994)\end{array}$ & $\begin{array}{c}0.249 \\
(10.533)\end{array}$ \\
\hline$T H_{t-1} D C_{t-1}$ & & & & & & $\begin{array}{c}0.018 \\
(1.621)\end{array}$ & & \\
\hline$T H_{t-2}$ & & & & & & & $\begin{array}{l}-0.135 \\
(-4.905)\end{array}$ & $\begin{array}{l}-0.080 \\
(-2.672)\end{array}$ \\
\hline$m k t_{t-1}^{+}$ & & & & & $\begin{array}{c}0.148 \\
(9.951)\end{array}$ & $\begin{array}{c}0.141 \\
(9.156)\end{array}$ & & \\
\hline$m k t_{t-1}^{-}$ & & & & & $\begin{array}{c}0.186 \\
(13.093)\end{array}$ & $\begin{array}{c}0.178 \\
(11.849)\end{array}$ & & \\
\hline$m k t_{t-1}^{+} D C_{t-1}$ & & & & $\begin{array}{c}-0.042 \\
(-2.174)\end{array}$ & & $\begin{array}{l}-0.083 \\
(-2.535)\end{array}$ & & $\begin{array}{c}0.037 \\
(1.749)\end{array}$ \\
\hline$m k t_{t-1}^{-} D C_{t-1}$ & & & & $\begin{array}{c}0.052 \\
(2.772)\end{array}$ & & $\begin{array}{l}-0.042 \\
(-1.763)\end{array}$ & & $\begin{array}{l}-0.028 \\
(-1.845)\end{array}$ \\
\hline
\end{tabular}

Table 8: Estimated Coefficient (t-stat in parenthesis) for PH, SI, TA, TH. Jul. 1995 - Dec. 2006. 